\title{
Nearest neighbors as foraging cues: information transfer in a patchy environment
}

\author{
Emily D. Silverman ${ }^{1, *}$, Richard R. Veit ${ }^{2}$, Gabrielle A. Nevitt ${ }^{3}$ \\ ${ }^{1}$ School of Natural Resources \& Environment, University of Michigan, 430 E. University, Ann Arbor, Michigan 48109-1115, USA \\ ${ }^{2}$ Department of Biology, College of Staten Island, City University of New York, 2800 Victory Boulevard, Staten Island, \\ New York 10314, USA \\ ${ }^{3}$ Center for Neuroscience, University of California, Davis, 1544 Newton Court, Davis, California 95616, USA
}

\begin{abstract}
To assess the importance of both conspecifics and heterospecifics as cues to prey location, we analyzed patterns of seabird species co-occurrence along shipboard transects conducted near South Georgia $\left(55^{\circ} \mathrm{S}, 35^{\circ} \mathrm{W}\right)$ during the austral summer. Using data collected over $9 \mathrm{~d}$ and $1500 \mathrm{~km}$ ocean, we focused on the behavior of 4 seabird species that are abundant in Antarctic waters: black-browed albatross Thalassarche melanophrys, white-chinned petrel Procellaria aequinoctialis, prion Pachyptila spp., and diving petrel Pelecanoides spp. We identified and recorded the behavior of the nearest neighbors of focal, flying individuals and demonstrated strong intraspecific associations for all 4 species. More conspecific neighbors of prions and diving petrels were also observed flying than expected due to chance. This result suggests that these birds may forage co-operatively with conspecifics. In contrast, more heterospecific neighbors were feeding than expected, and more heterospecific neighbors of white-chinned petrels, prions, and diving petrels were black-browed albatross and groups of penguins and Antarctic fur seals Arctocephalus gazella than expected by chance. We show that associations among foraging birds are not random and are not due to speciesspecific differences in foraging habitat. We present methods that can be used to measure and compare the strength of intra- and interspecific association among predators at sea. Our results suggest that local enhancement is an important component of the foraging strategies of Antarctic seabirds.
\end{abstract}

KEY WORDS: Seabirds - Foraging $\cdot$ Nearest neighbor $\cdot$ Black-browed albatross $\cdot$ Local enhancement $\cdot$ South Georgia $\cdot$ Compositional data analysis

Resale or republication not permitted without written consent of the publisher

\section{INTRODUCTION}

Mixed-species assemblages of foraging animals form for numerous reasons, including protection from predation and increased foraging efficiency (e.g. Morse 1977, Diamond 1981, Barnard \& Thompson 1985, Powell 1985). Some aggregations, however, are likely to result from passive processes, such as accumulation at a resource patch (Evans 1982, Mitani et al. 1991, Gerard et al. 2002). Unlike some terrestrial birds and aquatic birds such as pelicans and avocets (del Hoyo et al. 1992, 1995), pelagic seabirds have not generally been observed to cooperate in groups when searching for and capturing prey. Instead, large aggregations of feeding seabirds are believed to result from the accumulation of independent foragers at prey patches (Hoffman et al. 1981, Duffy 1989, Harrison et al. 1991, Haney et al. 1992, Shealer 2002). One important cue that pelagic seabirds use to find prey may be the behavior of other seabirds, a strategy called local enhancement (e.g. Pöysä 1992, Buckley 1996, 1997). A number of studies have provided evidence that predators make use of local enhancement (e.g. Hoffman et al. 1981, Porter \& Sealy 1982, Bayer 1983, Grover \& Olla 1983, Chilton \& Sealy 1987, Haney et al. 1992, Mahon et al. 1992, Camphuysen \& Webb 1999, Grunbaum \& Veit 2003), although researchers have also suggested that seabirds forage 
cooperatively in loose knit flocks or networks (Wittenberger \& Hunt 1985).

The large foraging ranges and high mobility of seabirds hinder the collection of data on their behavior. Albatrosses and other procellariform seabirds travel hundreds of kilometers on single foraging trips (Jouventin \& Weimerskirch 1990, Weimerskirch et al. 1993, Prince et al. 1997) and much remains unknown about how they find prey. To date, there has been no broadscale analysis of nearest-neighbor associations among pelagic seabirds outside of feeding aggregations. The quantification of intra- and interspecific foraging associations is critical for any description of the mechanisms of feeding flock formation, as well as for an understanding of the basic strategies pelagic seabirds use to locate prey patches. In this paper, we analyze data collected in the Southern Ocean around South Georgia $\left(55^{\circ} \mathrm{S}, 35^{\circ} \mathrm{W}\right)$ during the austral summer, with the goal of understanding the role of intra- and interspecific associations in the foraging behavior of individual seabirds. We explore spatial association among individuals to determine whether their foraging behavior is truly independent or whether they forage in groups. We also consider the extent to which birds use particular species as local resource cues.

Among the diverse community of seabirds and marine mammals that breeds on South Georgia, many species feed predominantly on Antarctic krill Euphausia superba (Croxall \& Prince 1980, Croxall et al. 1997a), which is patchily and often unpredictably distributed (Daly \& Macaulay 1988, Brierley et al. 1997). There are 2 primary reasons why intra- and interspecific interactions might be critical to the discovery and exploitation of prey by South Georgia's seabird community. First, these seabird species exhibit a high degree of dietary overlap and little segregation in their feeding areas (Croxall \& Prince 1980, Ainley et al. 1984, Veit 1988, Fraser et al. 1989, Rau et al. 1992, Croxall et al. 1997a). Second, mixed species feeding aggregations are ubiquitous and there is evidence that flying seabirds associate with marine mammals and diving seabirds (Harrison et al. 1991, Silverman \& Veit 2001). Studies of mixed-species flocks around South Georgia have revealed both positive and negative interactions among species when feeding (Veit 1988, Harrison et al. 1991, Silverman \& Veit 2001).

In this study, we present the results of analyses aimed at elucidating relationships among birds at sea. First, we quantified the extent to which foraging seabirds are associated with conspecifics, by considering the identity of the nearest neighbors of individual birds. In this analysis, we compared the relative proportion of conspecific neighbors to the proportion expected due to chance; we also measured foraging group size. Second, we investigated the behavior of neighbors to determine whether birds were associated because they were foraging in groups or using other birds as resource cues. In this case, we assessed how birds responded to individuals of their own species and to other species by analyzing the behavior of both conspecific and heterospecific neighbors. Third, to determine whether foraging birds were more likely to associate with species that might serve as resource cues, we measured the association of individual foragers with (1) albatrosses and (2) seals and penguins. Finally, we considered whether spatial segregation of species within the study area could explain the observed patterns of association.

\section{MATERIALS AND METHODS}

Data collection. We conducted strip transects (Tasker et al. 1984) near South Georgia between 9 January and 21 February 1994 (Fig. 1). Observations within a $100 \mathrm{~m}$ wide strip, centered $100 \mathrm{~m}$ ahead of the bow, were made from the bridge of the RRV 'James Clark Ross'. Two people collected data: one observed with binoculars while the other entered the observations into a laptop computer that recorded time to the nearest $0.1 \mathrm{~min}$ for each observation. We recorded the identity and behavior of all birds and marine mammals observed within the strip. The behaviors recorded included flying, ship-following, porpoising (for seals and penguins), and 7 activities associated with feeding and resting: sitting, milling, pattering, diving, capturing prey, hitting the water, and landing. Ship followers were removed from the analyses. These data represent observations of over 25000 seabirds and Antarctic fur seals Arctocephalus gazella during more than $82 \mathrm{~h}$ of surveys that covered $1500 \mathrm{~km}$ of ocean, collected while steaming at between 8 and 12 knots.

We combined observations from all transects conducted on the same day and report results for 4 species: black-browed albatross Thalassarche melanophrys, white-chinned petrel Procellaria aequinoctialis, prion Pachyptila spp. (P. desolata and P. belcheri), and diving petrel Pelecanoides spp. ( $P$. georgicus and $P$. urinatrix). We chose these species because they are abundant in South Georgia waters and differ in foraging behavior and diet. Black-browed albatrosses are relatively omnivorous but take more krill than any other prey item. They commonly feed in mixed-species flocks, and their conspicuous black-and-white plumage may serve as a foraging cue for other birds (Simmons 1972, Bretagnolle 1993, Croxall et al. 1997a). White-chinned petrels, by contrast, lack striking plumage features, feed mostly on squids and fishes, catch a large proportion of their prey at night, and may depend heavily on olfaction when foraging (Croxall \& 
Prince 1980, Nevitt et al. 1995). Prions form large monospecific foraging flocks and capture mainly copepods and small euphausiids (Prince 1980, Cherel et al. 2002). Diving petrels similarly concentrate on copepods and small euphausiids and tend to feed separately from other species. (Payne \& Prince 1979, Croxall \& Prince 1980, Veit 1988, Reid et al. 1997, Bocher et al. 2000).

Statistical analyses. Our analyses focused upon flying birds, based on the rationale that they were likely to be searching for food rather than feeding. Sitting birds, on the other hand, were likely to have found a prey patch (Veit 1999). For each flying bird, we determined the identity and behavior of the 'nearest neighbor.' We defined the nearest neighbor as the next bird or seal observed along the transect, regardless of behavior. For each analysis, we grouped all data collected on a single day, so that we had 1 data point for each day. This choice resulted in a huge reduction in our effective sample size $(n=9)$.

Conspecific association: To determine whether nearest neighbors were likely to be conspecifics, we compared observed neighbor identities to species compositions derived from daily transect counts. Given no association, the probability that a neighbor is a conspecific should equal the proportional abundance of the species. Thus, we calculated the proportion of neighbors that were conspecific for each day (Table 1, Quantity 2) and compared these proportions to the species' proportional abundance ( $p_{i j}$ i Table 1, Quantity 1) on that day.

We used a Monte-Carlo procedure (Manly 1997) to test the null hypothesis that conspecific neighbors were drawn randomly from the background species composition. We first generated the number of conspecific neighbors for species $i, x_{i j}$ as a realization of a binomial random variable with parameters $F_{i j}$ and $p_{i j}$ (Table 1 ) for Days $j=1,2, \ldots, 9$, and calculated the corresponding proportion of conspecific neighbors, $x_{i j} / F_{i j}$. We then computed the paired-sample $t$-statistic to compare the 9 simulated proportions to the expected proportions (the $p_{i j} \mathrm{~s}$ ). This procedure, repeated 1999 times for each species, generates the null distribution of the test statistic (see Manly 1997). We chose the $t$-statistic because it incorporates information about the magnitude of differences between pairs. To account for multiple testing and insure an overall $\alpha$ level of 0.05, we used a Bonferroni corrected $\alpha$-level of 0.0125 for the 4 individual species tests. We calculated overall p-values by multiplying the largest $p$-value in each set of tests by 4 .

We defined sequential records of flying conspecifics as foraging groups. We calculated the size of all foraging groups and average group size, by species, over the $9 \mathrm{~d}$. We also calculated the average group size

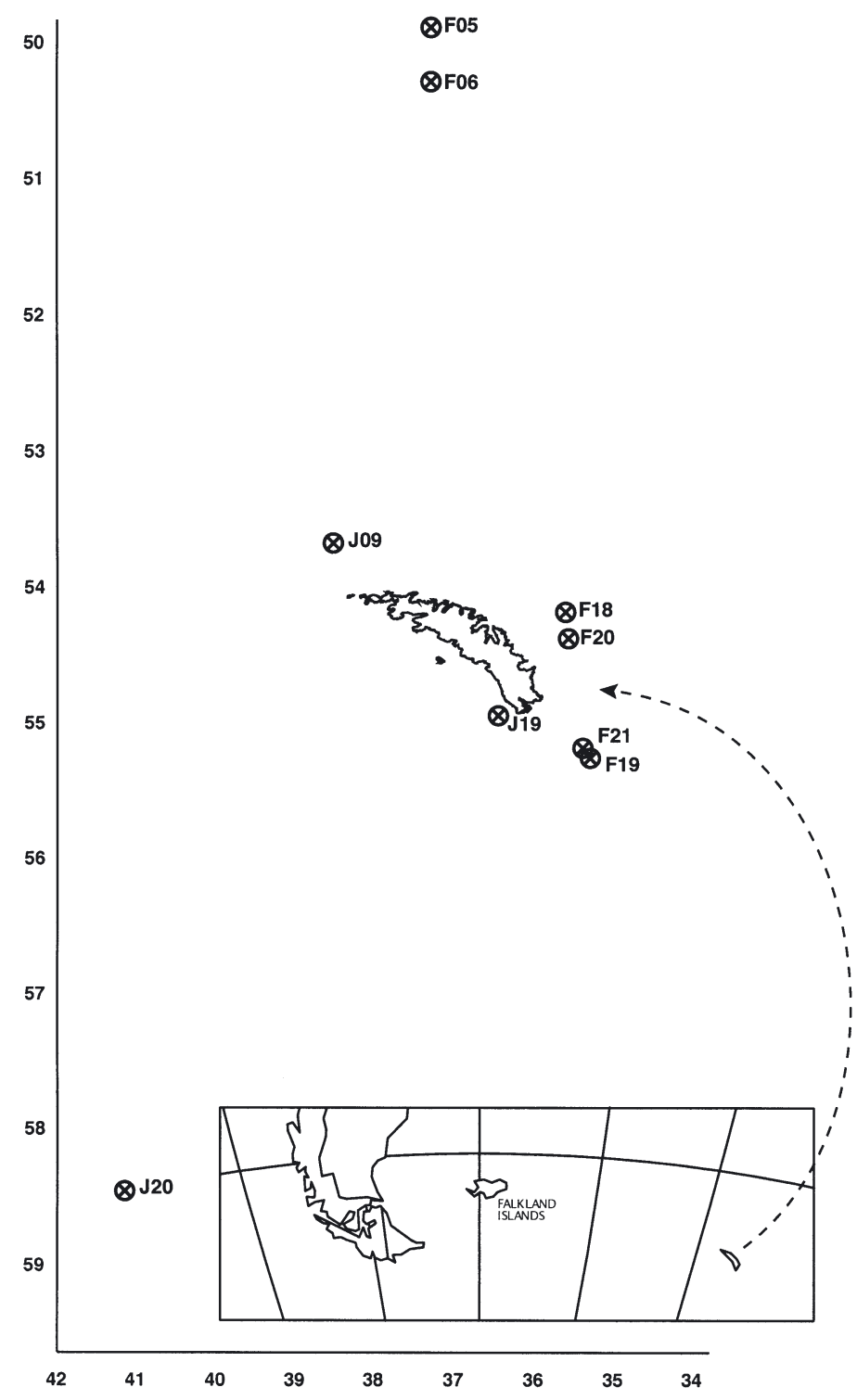

Fig. 1. Location of transects by day. Circles represent the average latitude and longitude. $\mathrm{J}=$ January, $\mathrm{F}=$ February. Numbers indicate the day of the month

expected if the species were distributed randomly along the transects $\left(\left[1-p_{i j}\right]^{-1}\right.$; Pielou 1977). We compared observed average group size to the expected size for each species using the Wilcoxon paired-sample test (Zar 1999); observed groups that were significantly larger than expected indicated conspecific association.

Reasons for association: To distinguish between group foraging (in which foragers associate before prey is located) and local enhancement (in which foragers associate after prey is found), we considered conspecific neighbors separately from heterospecific neighbors.

To explore conspecific association, we asked if more conspecific neighbors were flying than would be 
Table 1. Variables used in the analyses. All variables were calculated for each of the 9 survey days, represented by the subscript $j$. The subscript $i$ indicates the species (black-browed albatross, white-chinned petrel, prion spp., or diving petrel spp.). Quantities 1-6 are calculated separately for each of the 4 species of interest. Quantity 7 is calculated for white-chinned petrel, prion, and diving petrel

\begin{tabular}{|c|c|c|c|}
\hline Variable & Definition & Quantity & Formula \\
\hline$N_{j}$ & Total birds and fur seals & \multirow[t]{2}{*}{$\begin{array}{l}\text { 1. Proportional representation, } \\
\text { species } i \text {, day } j\end{array}$} & $S_{i j}$ \\
\hline$S_{i j}$ & Total birds of species $i$ & & $p_{i j}=\frac{i_{j}}{N_{j}}$ \\
\hline$F_{i j}$ & $\begin{array}{l}\text { Number of focal birds, } \\
\text { species } i\end{array}$ & \multirow[t]{2}{*}{$\begin{array}{l}\text { 2. Proportion of neighbors that } \\
\text { were conspecifics }\end{array}$} & $=\frac{C_{i j}}{F_{i j}}$ \\
\hline$C_{i j}$ & $\begin{array}{l}\text { Number of conspecific } \\
\text { neighbors of focal birds, species } i\end{array}$ & & \multirow{3}{*}{$j=\frac{N_{(F \times F) j}}{N_{(F) j}}$} \\
\hline$N_{(F) j}$ & Number of flying birds & \multirow[t]{2}{*}{$\begin{array}{l}\text { 3. Proportion of all flying birds } \\
\text { with flying neighbors }\end{array}$} & \\
\hline$N_{(F \times F) j}$ & $\begin{array}{l}\text { Number of flying birds with } \\
\text { flying neighbors }\end{array}$ & & \\
\hline$C_{(F) i j}$ & $\begin{array}{l}\text { Number of conspecific } \\
\text { neighbors that were flying }\end{array}$ & $\begin{array}{l}\text { 4. Proportion of conspecific neighbors } \\
\text { that were flying }\end{array}$ & $=\frac{C_{(F) i j}}{C_{i j}}$ \\
\hline$H_{(F) i j}$ & $\begin{array}{l}\text { Number of heterospecific } \\
\text { neighbors that were flying }\end{array}$ & $\begin{array}{l}\text { 5. Proportion of heterospecific neighbors } \\
\text { that were flying }\end{array}$ & $=\frac{H_{(F) i j}}{F_{i j}-C_{i j}}$ \\
\hline$H_{(P) i j}$ & $\begin{array}{l}\text { Number of penguin and fur } \\
\text { seal neighbors }\end{array}$ & $\begin{array}{l}\text { 6. Proportion of heterospecific neighbors } \\
\text { that were penguins or fur seals }\end{array}$ & $=\frac{H_{(P) i j}}{F_{i j}-C_{i j}}$ \\
\hline$H_{(A) i j}$ & $\begin{array}{l}\text { Number of albatross neighbors, for } \\
\text { species = white-chinned petrel, prion, } \\
\text { and diving petrel }\end{array}$ & $\begin{array}{l}\text { 7. Proportion of heterospecific neighbors } \\
\text { that were black-browed albatross }\end{array}$ & $=\frac{H_{(A) i j}}{F_{i j}-C_{i j}}$ \\
\hline
\end{tabular}

expected due to chance. We compared the proportion of flying conspecific neighbors (Table 1, Quantity 4) to the proportion of flying neighbors of all birds, regardless of species $\left(p_{(F \times F)}\right.$; Table 1, Quantity 3$)$ for each of the 4 focal species. If conspecific neighbors were more likely to be flying than predicted based on the overall daily proportion of flying neighbors, then we concluded that conspecifics forage together.

To determine if other species might be used as cues to prey availability, we asked if fewer heterospecific neighbors were flying than expected due to chance. We compared the proportion of flying heterospecific neighbors (Table 1, Quantity 5) with $p_{(F \times F)}$. If a lower proportion of heterospecific neighbors were flying than predicted based on the overall daily proportion of flying neighbors, then we concluded that the focal species associates with other species engaged in feeding.
We used the same Monte Carlo test procedure described above for these comparisons. In this case, $p_{i}$ is replaced by the $p_{(F \times F)}$.

Association with albatrosses, penguins and fur seals: Antarctic seabirds likely use conspicuous birds like black-browed albatrosses, and also penguins and fur seals, as cues to the location of prey (Harrison et al. 1991, Bretagnolle 1993, Grunbaum \& Veit 2003). We therefore extended our nearest neighbor analysis in order to quantify heterospecific associations and to explore the identity of neighbors. For white-chinned petrels, prions, and diving petrels, we calculated the proportion of heterospecific neighbors that belonged to 1 of 3 groups: (1) black-browed albatrosses (Table 1, Quantity 7); (2) penguins and fur seals (Table 1, Quantity 6); and (3) other heterospecifics (1 - Quantities $6+7)$. We then calculated the proportions of hetero- 
specifics in each of these 3 groups based on the daily transect counts.

These calculations yielded 9 paired compositions for each focal species. We transformed the paired compositions using the additive log-ratio transform (Aitchison 2003). For a composition of length 3 , the transformation entails dividing the first 2 proportions by the third and then taking the logarithm. We divided the proportion of albatross neighbors and the proportion of non-flying predator neighbors by the proportion of other heterospecific neighbors. Similar calculations transformed the overall background compositions of albatross, nonflying predators, and other heterospecifics. The resulting vectors, of length 2 , should be approximately normally distributed. Because other heterospecifics always outnumbered albatrosses and non-flying predators, the transformed values were negative. Values closer to zero indicate a higher relative proportion of albatross or non-flying neighbors.

We used Hotelling's $T^{2}$-test (Rencher 1995) to compare the observed proportions to the background proportions. The compositions should not differ if heterospecific neighbors represent a random draw from all heterospecifics present. When the Hotelling's test was significant, we conducted a posteriori paired sample $t$ tests on the individual components of the transformed composition to determine which components explained the heterospecific association (Rencher 1995). Because the small sample sizes do not provide protection against non-normality, we also conducted an alternative, Monte Carlo test, procedure. The results of this procedure did not differ from the standard Hotelling's $T^{2}$-test results and the $p$-values were very similar.

For black-browed albatrosses, we compared the mean proportion of penguin and fur seal neighbors (Table 1, Quantity 6) to the proportions predicted based on the transect counts (Wilcoxon paired-sample test).

Spatial segregation in habitat use: Segregation of species among habitats could cause foraging associations to be measured incorrectly, if, for example, the daily transects crossed distinct oceanographic habitats. To explore this possibility, we calculated the correlation between the abundance of each focal species and its heterospecifics for $5 \mathrm{~min}$ sections of transects. We repeated this calculation using sections of 2, 10, and 20 min. Negative correlations suggest that significant conspecific associations in the Monte Carlo test may be due to differential use of ocean habitat; for example, diving petrels may be abundant in different habitats than other seabirds. On the other hand, positive correlations indicate attraction to similar areas and support our analysis of association.

We also calculated correlations between the abundance of each focal species and the 3 categories of heterospecifics (albatrosses, penguin/fur seal groups, and 'other'). We used abundance of penguin and fur seal groups for these correlations because results of the compositional tests suggested that the focal species might be responding to groups of non-flying predators, rather than to individuals. For black-browed albatrosses, we calculated correlations only for the second and third categories. Strong positive correlations with one category, and negative correlations with another, would indicate that spatial segregation explained differential association with the 3 categories of heterospecifics.

Finally, we plotted the daily correlations versus a measure of the strength of conspecific association for each day $\left(C_{i j} / F_{i j}-p_{i j}\right)$. A negative relationship between these quantities (i.e. higher conspecific association with negative correlation in abundance) suggests that conspecific association is a consequence of spatial segregation. In all cases, our conclusions were identical for all time segments considered, so we report results for the 5 min intervals only.

Table 2 summarizes our analyses and results.

\section{RESULTS}

\section{Conspecific association}

We found a high degree of conspecific association for all 4 species (Fig. 2a, overall $p=0.03[4 \times 0.007$, see 'Materials and methods']). On average, prions made up $44 \%$ of the predators counted, but $69 \%$ of their neighbors were also prions. Similarly, white-chinned petrels, black-browed albatrosses, and diving petrels averaged 4,4 , and $8 \%$ of the all predators, respectively, with 14 , 16 , and $35 \%$ of their neighbors recorded as conspecifics. Consequently, foraging group sizes were significantly larger than expected for all 4 species (Table 3, overall $\mathrm{p}=0.03$ ). The absolute difference in observed and expected mean group size was greatest for prions and diving petrels, while the differences relative to their standard errors were greatest for blackbrowed albatrosses and white-chinned petrels (Table $3)$. Thus, the group size analysis indicates strong intraspecific associations among both black-browed albatrosses and white-chinned petrels; smaller foraging group sizes of these species were due to their relatively low abundance and do not indicate weak intraspecific associations.

\section{Reasons for association}

For prions and diving petrels, more conspecific neighbors were flying than expected due to chance, suggesting that these species forage together in groups (Table 4 , individual p-values $<0.002$ ). We 
Table 2. Summary of analyses and results. All analyses were conducted using flying birds as the focal individuals. Column 2 indicates the behavior of the nearest neighbors considered in each analysis

\begin{tabular}{|c|c|c|c|c|c|}
\hline Analysis & Neighbor & Behavior & Question & Species & Result \\
\hline $\begin{array}{l}\text { Conspecific } \\
\text { association }\end{array}$ & Conspecifics & All & $\begin{array}{l}\text { Are neighbors more likely to } \\
\text { be conspecifics? }\end{array}$ & $\begin{array}{l}\text { Prion spp. } \\
\text { Diving petrel spp. } \\
\text { White-chinned petrel } \\
\text { Black-browed albatross }\end{array}$ & $\begin{array}{l}\text { Yes, } p<0.001 \\
\text { Yes, } p=0.003 \\
\text { Yes, } p=0.007 \\
\text { Yes, } p<0.001\end{array}$ \\
\hline \multirow[t]{2}{*}{$\begin{array}{l}\text { Reason for } \\
\text { association }\end{array}$} & Conspecifics & Flying & $\begin{array}{l}\text { Are conspecific neighbors } \\
\text { more likely to be flying? }\end{array}$ & $\begin{array}{l}\text { Prion spp. } \\
\text { Diving petrel spp. } \\
\text { White-chinned petrel } \\
\text { Black-browed albatross }\end{array}$ & $\begin{array}{l}\text { Yes, } p<0.002 \\
\text { Yes, } p<0.002 \\
\text { Maybe, } p=0.20 \\
\text { (see text) } \\
\text { No, } p=0.47\end{array}$ \\
\hline & Heterospecifics & Flying & $\begin{array}{l}\text { Are heterospecific neighbors } \\
\text { less likely to be flying? }\end{array}$ & $\begin{array}{l}\text { Prion spp. } \\
\text { Diving petrel spp. } \\
\text { White-chinned petrel } \\
\text { Black-browed albatross }\end{array}$ & $\begin{array}{l}\text { Yes, } p=0.002 \\
\text { Yes, } p=0.002 \\
\text { Maybe, } p=0.06 \\
\text { Yes, } p=0.01\end{array}$ \\
\hline \multirow[t]{3}{*}{$\begin{array}{l}\text { Heterospecific } \\
\text { association }\end{array}$} & $\begin{array}{l}\text { Black-browed } \\
\text { albatross }\end{array}$ & All & $\begin{array}{l}\text { Are heterospecific neighbors } \\
\text { more likely to be albatross? }\end{array}$ & $\begin{array}{l}\text { Prion spp. } \\
\text { Diving petrel spp. } \\
\text { White-chinned petrel }\end{array}$ & $\begin{array}{l}\text { Yes, } p=0.02 \\
\text { Yes, } p=0.01 \\
\text { Yes, } p=0.003\end{array}$ \\
\hline & $\begin{array}{l}\text { Penguins and } \\
\text { fur seals }\end{array}$ & All & $\begin{array}{l}\text { Are heterospecific neighbors } \\
\text { more likely to be individual } \\
\text { penguins and fur seals? }\end{array}$ & $\begin{array}{l}\text { Prion spp. } \\
\text { Diving petrel spp. } \\
\text { White-chinned petrel } \\
\text { Black-browed albatross }\end{array}$ & $\begin{array}{l}\text { Maybe, } p=0.06 \\
\text { No, } p=0.53 \\
\text { No, } p=0.91 \\
\text { No, } p=0.82\end{array}$ \\
\hline & $\begin{array}{l}\text { Penguins and } \\
\text { fur seals }\end{array}$ & All & $\begin{array}{l}\text { Are heterospecific neighbors } \\
\text { more likely to be groups of } \\
\text { penguins and fur seals? }\end{array}$ & $\begin{array}{l}\text { Prion spp. } \\
\text { Diving petrel spp. } \\
\text { White-chinned petrel } \\
\text { Black-browed albatross }\end{array}$ & $\begin{array}{l}\text { Maybe, } p=0.08 \\
\text { Maybe, } p=0.09 \\
\text { Yes, } p=0.02 \\
\text { No, } p=0.28\end{array}$ \\
\hline
\end{tabular}

found no significant association for black-browed albatrosses or white-chinned petrels (Table 4, individual p-values of 0.47 and 0.20 , respectively). For whitechinned petrels, however, the average percentage of flying conspecific neighbors (95\%) was substantially above the overall average of $90 \%$. The lack of significance may be due to low statistical power, although the strength of conspecific foraging associations among white-chinned petrels appears weaker than among prions and diving petrels. Failure to detect black-browed albatross and white-chinned petrel foraging groups could also be due to the fact that they associate at distances greater than we can detect with nearest neighbor data. Our tests are conservative measures of association, because the birds may associate with individuals beyond their nearest neighbor.

For prions, diving petrels, and black-browed albatrosses, heterospecific neighbors were less likely to be flying than expected (Table 4 , individual p-values of 0.002, 0.002 and 0.01, respectively). The difference was not significant for white-chinned petrels ( $p=0.06)$. For all 4 species, the percentage of flying heterospecific neighbors was always less than expected, except when the ship was located more than 100 nautical miles offshore at depths of greater than $2000 \mathrm{~m}$.

\section{Association with albatrosses, penguins and fur seals}

The composition of heterospecific neighbors could not be explained by the relative proportions of heterospecifics on the transects $\left(T^{2}=5.99,10.62,13.11, \mathrm{n}=8,6\right.$, 7 , and $p=0.05,0.04$ and 0.01 , for prions, diving petrels, and white-chinned petrels, respectively). Albatross and non-flying neighbors were more common than expected (Table 5). The difference between the average for the nearest neighbors and for the background quantifies the

Table 3. Mean foraging group size by species (SD) for $\mathrm{n}=9 \mathrm{~d}$. Differences between observed group size and expected size are statistically significant for all species (Wilcoxon paired-sample test, overall $\mathrm{p}=0.03$ ). The last row reports the observed $t$-statistic, measuring the difference between the means in units of the SE

\begin{tabular}{|lcccc|}
\hline & $\begin{array}{c}\text { Black-browed } \\
\text { albatross }\end{array}$ & $\begin{array}{c}\text { White-chinned } \\
\text { petrel }\end{array}$ & $\begin{array}{c}\text { Prion } \\
\text { species }\end{array}$ & $\begin{array}{c}\text { Diving petrel } \\
\text { species }\end{array}$ \\
\hline Observed & $1.19(0.08)$ & $1.18(0.13)$ & $6.05(4.26)$ & $2.18(1.51)$ \\
Expected & $1.04(0.02)$ & $1.04(0.02)$ & $2.18(1.12)$ & $1.09(0.14)$ \\
Difference of SE & 6.26 & 3.69 & 3.45 & 2.36 \\
\hline
\end{tabular}


(a) Conspecific neighbors

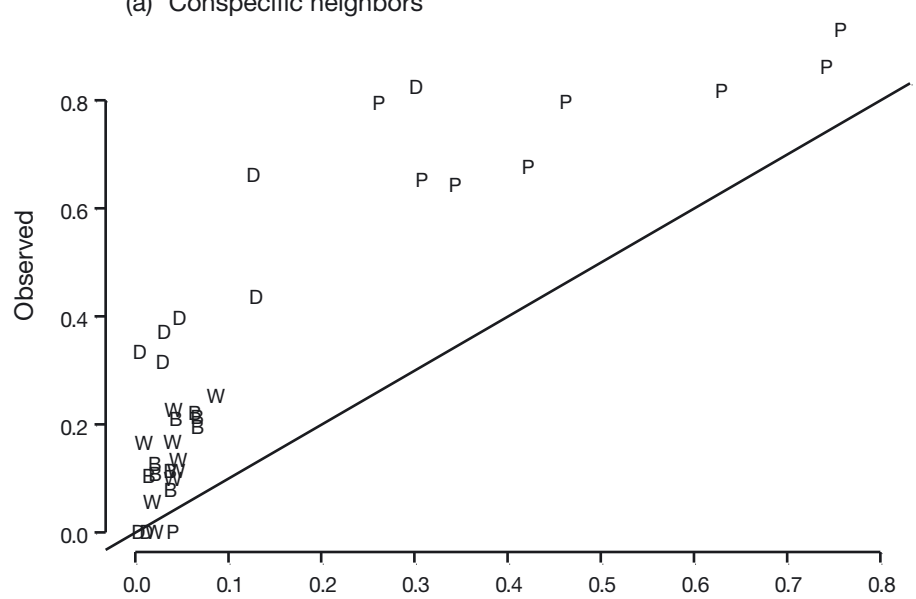

(c) Albatross neighbors

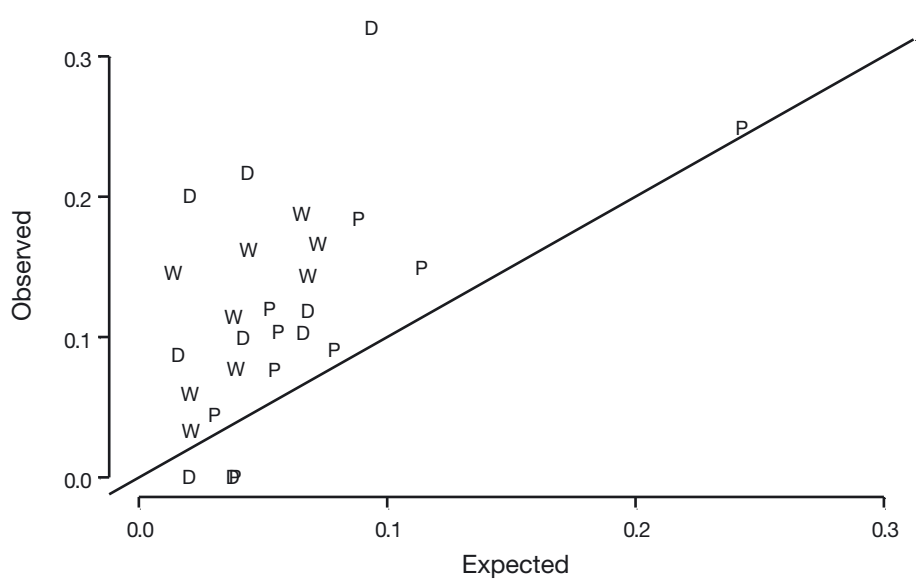

(b) Penguin \& seal neighbors
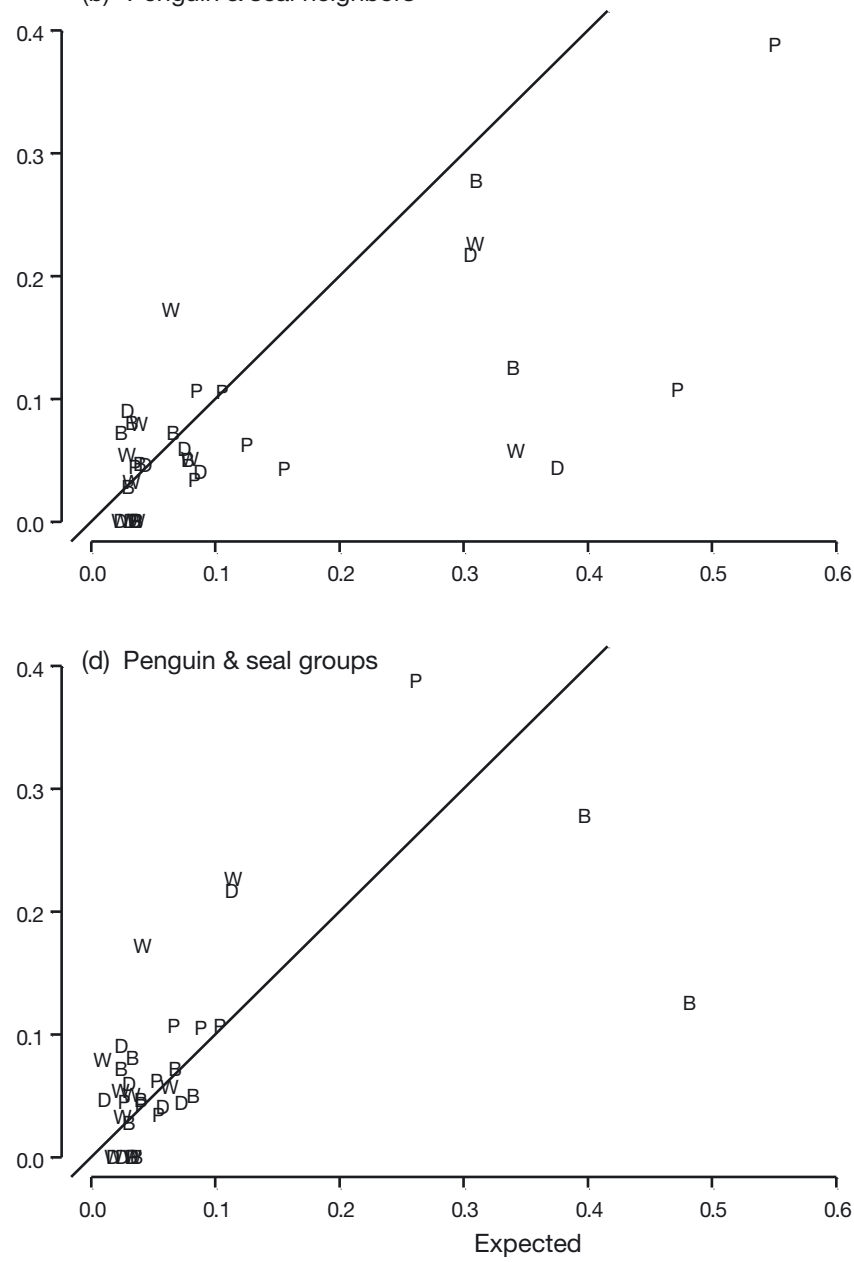

Fig. 2. (a) Observed (Table 1, Quantity 2) and expected (Table 1, Quantity 1) proportion of conspecific neighbors by day for each of the 4 species: black-browed albatross (B), diving petrel species (D), prion species (P), and white-chinned petrel (W). Solid line represents the $45^{\circ}$ line along which the data should fall if the observed proportion equaled the proportion expected if neighbors were random. (b) Observed proportion of penguins and fur seals among heterospecific neighbors (Table 1, Quantity 6) versus expected proportion of penguins and fur seals among heterospecific neighbors by day. (c) Observed proportion of black-browed albatrosses among heterospecific neighbors (Table 1, Quantity 7) versus expected proportion of black-browed albatrosses among heterospecific neighbors by day for diving petrel species, prion species, and white-chinned petrel. (d) Observed proportion of penguin and fur seal groups among heterospecific neighbors (Table 1, Quantity 6, calculated using number of penguin/fur seal groups) versus expected proportion of penguins and fur seals groups among heterospecific neighbors by day

strength of association and appears strongest for whitechinned petrels (1.19 and 0.99 for albatross and nonflying predator associations, respectively, Table 5), followed by diving petrels, and then prions.

A posteriori paired $t$-tests indicated that the 3 species associated with black-browed albatrosses (individual $p$-values of $0.02,0.01$ and 0.003 , for prions, diving petrels and white-chinned petrels, respectively) and not penguins and fur seals ( $p$-values of 0.06, 0.53 and 0.91). Similarly, black-browed albatrosses showed no association with penguins and fur seals (Wilcoxon's $=25, \mathrm{n}=9, \mathrm{p}=0.82$ ). Fig. 2c clearly illustrates the associations of prions, diving petrels and white-chinned petrels with black-browed albatrosses. There was no association between any of the 4 focal species and penguins and fur seals (Fig. 2b).

For diving petrels, prions, and white-chinned petrels, the variance of the transformed compositions is smaller for neighbors than for the background (Table 5). Total variance of the background composition of heterospecifics (the sum the variance of the individual components; Aitchison 2003) was approximately 1.5 to 3 times larger than variance of nearest neighbors. Similarly, for black-browed albatrosses, the proportions of non-flying heterospecific neighbors varied less than the proportions of penguins and fur seals in the community. 
Table 4. Percentage of flying birds' neighbors that are also flying. Columns 2 to 5 report Quantity 4 from Table 1 , Column 6 reports Quantity 3, $p_{(F \times F) j}$, and Columns 7 to 10 report Quantity 5. Values in bold indicate days when the percentage of flying neighbors of an individual species is less than the percentage of flying neighbors of all birds, $p_{(F \times F) j}$. $\mathrm{B}=$ black-browed albatross, $\mathrm{W}=$ white-chinned petrel, $\mathrm{P}=$ prion, $\mathrm{D}=$ diving petrel. NA: not available

\begin{tabular}{|c|c|c|c|c|c|c|c|c|c|}
\hline \multirow[t]{2}{*}{ Date } & \multicolumn{4}{|c|}{ Birds with conspecific neighbors } & \multirow[t]{2}{*}{ All birds } & \multicolumn{4}{|c|}{ Birds with heterospecific neighbors } \\
\hline & B & W & $\mathrm{P}^{\mathrm{b}}$ & $\mathrm{D}^{\mathrm{b}}$ & & $\mathrm{B}^{\mathrm{b}}$ & W & $\mathrm{P}^{\mathrm{b}}$ & $\mathrm{D}^{\mathrm{b}}$ \\
\hline Jan 9 & 95 & 100 & 98 & 98 & 93 & 77 & 82 & 86 & 78 \\
\hline Jan 19 & 71 & 86 & 100 & 100 & 91 & 82 & 74 & 87 & 76 \\
\hline $\operatorname{Jan} 20^{\mathrm{a}}$ & 100 & NA & 94 & NA & 91 & 92 & 84 & 82 & 43 \\
\hline Feb $5^{\mathrm{a}}$ & 50 & 100 & 91 & 100 & 89 & 86 & 94 & 91 & $\mathbf{5 0}$ \\
\hline Feb $6^{a}$ & 100 & 100 & NA & NA & 88 & 92 & 100 & 82 & 100 \\
\hline Feb 18 & 97 & 96 & 95 & 100 & 95 & 73 & 71 & 73 & 85 \\
\hline Feb 19 & 98 & 95 & 99 & 98 & 96 & 73 & 72 & 78 & 84 \\
\hline Feb 20 & 94 & 94 & 99 & 94 & 83 & 63 & 69 & 56 & 65 \\
\hline Feb 21 & 75 & 92 & 96 & 100 & 90 & 82 & 88 & 82 & 86 \\
\hline
\end{tabular}

${ }^{a}$ Days when observations were made offshore

${ }^{b}$ Significant differences between individual species and all birds, overall $\alpha=0.05$. Conspecific neighbor comparisons and heterospecific neighbor comparisons were separately adjusted for an overall $\alpha=0.05$, so that individual tests were significant if $\mathrm{p}<0.0125$

Table 5. Mean and variance for the additive log-ratio transformed compositions by species. 'Albatross/Other' is the natural logarithm of the ratio of proportion of black-browed albatross to proportion of other heterospecifics. 'Non-flying/Other' is the natural logarithm of the ratio of the proportion of penguins and fur seals to proportion of other heterospecifics

\begin{tabular}{|lcccc|}
\hline \multirow{2}{*}{ Species } & \multicolumn{2}{c}{ Neighbors } & \multicolumn{2}{c|}{ Community } \\
& $\begin{array}{c}\text { Albatross/ } \\
\text { Other }\end{array}$ & $\begin{array}{c}\text { Non-flying/ } \\
\text { Other }\end{array}$ & $\begin{array}{c}\text { Albatross/ } \\
\text { Other }\end{array}$ & $\begin{array}{c}\text { Non-flying/ } \\
\text { Other }\end{array}$ \\
\hline Mean & & & & \\
Prion & -1.88 & -2.23 & -2.20 & -2.47 \\
Diving petrel & -1.59 & -2.41 & -2.78 & -3.14 \\
White-chin & -1.83 & -2.30 & -3.02 & -3.29 \\
Variance & & & & \\
Prion & 0.45 & 0.89 & 0.62 & 1.50 \\
Diving petrel & 0.08 & 0.59 & 0.46 & 1.50 \\
White-chin & 0.52 & 0.69 & 0.51 & 1.47 \\
\hline
\end{tabular}

Since the background proportions are calculated from much larger total numbers of predators than the neighbor proportions, this is the opposite of what might be expected. The result suggests that the observed heterospecific associations represent stable patterns across a wide range of background compositions.

The lack of association with penguins and fur seals was unexpected, and we surmised that our results could be due to the fact that foraging seabirds cue to groups of penguins and fur seals, and not to individuals. Analysis of associations among foraging penguins (Tremblay \& Cherel 1999) provides support for treating penguin groups as distinct units. We repeated the Hotelling's $T^{2}$ test and the a posteriori $t$-tests using the abundance of groups of penguins and fur seals to calculate the expected distribution of heterospecific neighbors, instead of the total abundance of individu- als. The distribution of heterospecific neighbors still differed from that expected by chance (p-values of $0.003,0.02$, and 0.02 , for prions, diving petrels, and white-chinned petrels, respectively) and associations with black-browed albatrosses were still significant ( $\mathrm{p}=$ values of $0.02,0.01$, and 0.003). Associations with penguins and fur seals were marginally significant for the 3 smaller procellariform species ( $p$-values of $0.08,0.09$, and 0.02), but not for black-browed albatrosses ( $p=0.28$; Fig. 2d).

\section{Spatial segregation in habitat use}

The observed conspecific associations did not result from spatial segregation between the focal species and their heterospecifics. Mean correlation was not significantly different from zero for all 4 species ( $t$-test, $\mathrm{n}=9, \mathrm{p}>0.05$; Table 6 ) and the average correlation was positive in all cases, suggesting a slight tendency for focal species to occur at higher density within the same intervals as their heterospecifics. Overall, plots of daily correlation against the strength of conspecific association did not show a pattern of higher association when correlation with heterospecifics was negative. For prions, however, the day with the strongest conspecific association (20 January) also had the largest negative correlation, suggesting that some of their apparent conspecific association might be explained by spatial segregation between prions and other species.

Correlations in abundance between each species and the 3 categories of heterospecifics also did not differ sig- 
Table 6. Average daily correlation (SE) between focal species abundance and heterospecific abundance, based on 5 min intervals for $n=9 \mathrm{~d}$. $\mathrm{p}$-values are for the 1 -sample $t$-test. The last 3 rows report the correlations for the 3 categories of heterospecifics. NA: not applicable

\begin{tabular}{|lcccc|}
\hline & $\begin{array}{c}\text { Black-browed } \\
\text { albatross }\end{array}$ & $\begin{array}{c}\text { White-chinned } \\
\text { petrel }\end{array}$ & $\begin{array}{c}\text { Prion } \\
\text { species }\end{array}$ & $\begin{array}{c}\text { Diving petrel } \\
\text { species }\end{array}$ \\
\hline All hetero- & $0.07(0.03)$ & $0.05(0.04)$ & $0.15(0.08)$ & $0.04(0.08)$ \\
specifics & $\mathrm{p}=0.07$ & $\mathrm{p}=0.20$ & $\mathrm{p}=0.10$ & $\mathrm{p}=0.59$ \\
Black-browed & $\mathrm{NA}$ & $0.08(0.04)$ & $0.03(0.04)$ & $\begin{array}{c}-0.01(0.04) \\
\text { albatross }\end{array}$ \\
Penguin and fur & $0.04(0.02)$ & $0.07(0.05)$ & $0.09(0.05)$ & $0.03(0.08)$ \\
seal groups & $\mathrm{p}=0.15$ & $\mathrm{p}=0.20$ & $\mathrm{p}=0.12$ & $\mathrm{p}=0.75$ \\
Other hetero- & $0.06(0.03)$ & $0.03(0.03)$ & $0.18(0.07)$ & $0.09(0.08)$ \\
specifics & $\mathrm{p}=0.14$ & $\mathrm{p}=0.44$ & $\mathrm{p}=0.04$ & $\mathrm{p}=0.26$ \\
\end{tabular}

nificantly from zero (Table 6). Prions had a marginally significant positive correlation with the 'Other heterospecifics' category $(\mathrm{p}=0.04)$. For prions and diving petrels, the relative magnitudes of the correlations strengthened the results of the Hotelling's tests and did not support the alternative explanation of spatial segregation: the abundance of these 2 species was most positively correlated with other heterospecifics, followed by non-flying predators and then albatrosses. Thus, their association with black-browed albatrosses was significant, despite the fact that both species showed greater spatial segregation from albatrosses than from the 2 other heterospecific categories. White-chinned petrels showed a somewhat higher correlation with albatrosses and non-flying predators, which may explain their higher average association values and the smaller difference in variance between their transformed neighbor compositions and the community compositions (Table 5).

\section{DISCUSSION}

We found strong intraspecific associations for 4 species of pelagic seabirds that are usually thought to forage independently. Our analyses also suggest that black-browed albatrosses could serve as an indicator of resource availability.

The conspecific neighbors of prions and diving petrels were much more likely to be flying than expected by chance, suggesting that these species forage in conspecific groups. Our finding of association among flying, non-feeding prions and diving petrels is surprising and raises the possibility that these species form diffuse foraging flocks. If individuals of these species maintain a short enough inter-individual distance so as to remain in visual contact, and if they exploit one another's actions as cues to the presence of prey, then their behavior may in some respects resemble that of black-headed gulls Larus ridibundus in an experimental setting (Gotmark et al. 1986). Prions and diving petrels are each commonly found in large monospecific flocks separate from other species of seabirds, near South Georgia and elsewhere (Murphy 1936, Warham 1990, 1996, Veit 1988). This observation, coupled with the analysis presented here, suggests that group foraging by these petrels is a foraging strategy that deserves further attention.

The large numbers of prions present in some areas around South Georgia probably explains the fact that the largest negative correlation between the abundance of prions and their heterospecifics occurred on the same day (20 January) as the strongest measure of conspecific association. Nonetheless, despite their large numbers and tendency for intraspecific association, the correlation analysis does not suggest that prions are spatially segregated from other species. Thus, segregation due to monospecific flocking occurred on a smaller scale (100s of $\mathrm{m},<2$ min steaming time) than encompassed by our analyses.

In contrast to prions and diving petrels, blackbrowed albatrosses and white-chinned petrels were not more likely to associate with flying conspecifics. These large birds may forage with conspecifics, but space themselves at great enough distances so that the pattern is missed by shipboard surveys. For these 2 species, however, we cannot attribute their strong observed conspecific association to group foraging. This result highlights the difficulty of defining the boundary between cooperative foraging and local enhancement.

Other species appear to serve as resource cues for prions, diving petrels, and black-browed albatross, since their heterospecific neighbors were more likely to be feeding or sitting on the water than expected. This result was not significant for the white-chinned petrel. The lack of significance for white-chinned petrels may be explained by the survey location on the 2 days (5 and 6 February) when their proportion of flying heterospecifics was high: surveys on these days occurred during daylight, well offshore of krill feeding areas. In this area, white-chinned petrels may not have been foraging during the day and may rely more on olfaction and less on heterospecific cues.

For prions, diving petrels, and white chinned petrels, heterospecific neighbors were more likely to be blackbrowed albatrosses than the proportion of albatrosses in the community would suggest. There is also some evidence that prions, diving petrels, and whitechinned petrels associate with groups of penguins and 
fur seals. These observations strengthen the evidence that multispecies feeding flocks around South Georgia result from the processes of local enhancement and interspecific cueing.

Our current findings add to the accumulating evidence suggesting that black-browed albatross are a foraging cue for many seabirds (including other blackbrowed albatrosses). Black-browed albatrosses are large birds with distinctive black and white plumage and brightly colored bills. They are one of the most consistent participants of multispecies feeding flocks at South Georgia (Harrison et al. 1991, Silverman \& Veit 2001). Grunbaum \& Veit (2003) found that during a summer survey around South Georgia, the proportion of black-browed albatrosses feeding was more highly correlated with black-browed albatross abundance than with shipboard measurements of krill abundance. This finding underscores the importance of conspecific foraging cues. Several species of albatross, including black-browed albatross, have experienced substantial population declines in recent years (Croxall et al. 1997b, Birdlife International 2000). If, as suggested by our analyses, black-browed albatrosses are an important foraging cue, then it is possible that decreasing albatross abundance could accelerate their own decline and negatively affect the foraging success of other species. Given the complex nature of the top predator community in the Southern Ocean, we would recommend further investigation of interspecific associations focusing on the role of albatrosses.

Because flying seabirds are reported to respond to the presence of diving predators (Evans 1982, Grover \& Olla 1983, Harrison et al. 1991, Mahon et al. 1992, Camphuysen \& Webb 1999), stronger associations with black-browed albatrosses than with penguins and fur seals are interesting. During the summer of 1994, when the data analyzed here were collected, there was a severe scarcity of Antarctic krill near South Georgia. Although we observed seabirds feeding and detected plankton swarms using both echosounders and nets, virtually all newborn fur seal pups died, and all seabirds that feed substantially upon krill experienced the least successful reproductive season on record (Brierley et al. 1997). The patterns of association that we report may therefore represent the response of seabirds to unusually low prey availability. The fur seals we observed may not have been associated with krill swarms, and may not have been feeding, or may have been associated with krill that was inaccessible to surface feeding birds.

We speculate that flying birds respond to penguins and seals only when those predators exhibit behavior consistent with having found a surface krill patch. Birds may respond to albatrosses, on the other hand, whenever albatrosses mill about or alight on the water, which they do in response to many prey beside krill (authors' pers. obs.).

The analyses presented here should be extended to consider data from a breeding season of average or high krill abundance; such an analysis would provide an opportunity to determine how the behavioral associations we measured depend on prey scarcity. This would provide a more complete assessment of the importance of fur seal herds as foraging cues to birds. Further analysis should also consider how variables including prey and predator distribution and abundance, distance from colony, and environmental conditions affect the magnitude of association. Finally, despite differences in diet and foraging habits among our 4 focal species, we detected consistent patterns of conspecific and heterospecific association. Quantifying the differences and commonalities in foraging behavior among these species requires further investigation.

Acknowledgements. We are grateful to the captain, officers, and crew aboard the RRV 'James Clark Ross' and the British Antarctic Survey, who made this research possible. In particular, we thank P. A. Prince, M. J. Whitehouse, and J. P. Croxall. M. E. McPhee, D. Hyrenbach, D. Grémillet, and 3 anonymous reviewers provided helpful comments on the manuscript. This research was supported by National Science Foundation grant DPP 89-18130 to P. Kareiva and R.R.V., OPP 92-20128 to P. Kareiva, R.R.V., and J. Wingfield, and OPP-9983751 to R.R.V.

\section{LITERATURE CITED}

Ainley DG, O'Connor EF, Boekelheide RJ (1984) The marine ecology of birds in the Ross Sea, Antarctica. Ornithol Monogr 32:1-97

Aitchison J (2003) The statistical analysis of compositional data, 2nd edn. Blackburn Press, Caldwell, NJ

Barnard CJ, Thompson DBA (1985) Gulls and plovers: the ecology and behaviour of mixed-species feeding groups. Columbia University Press, New York

Bayer RD (1983) Black-legged Kittiwake feeding flocks in Alaska: selfish/reciprocal-altruistic flocks? J Field Ornithol 54:196-199

Birdlife International (2000) Threatened birds of the world. Lynx Edicions and Birdlife International, Barcelona and Cambridge

Bocher P, Cherel Y, Hobson KA (2000) Complete trophic segregation between South Georgian and common diving petrels during breeding at Iles Kerguelen. Mar Ecol Prog Ser 208:249-264

Bretagnolle V (1993) Adaptive significance of seabird coloration: the case of the Procellariiforms. Am Nat 142:141-173

Brierley AS, Watkins JL, Murray AW (1997) Interannual variability in krill abundance at South Georgia. Mar Ecol Prog Ser 150:87-98

Buckley NJ (1996) Food finding and the influence of information, local enhancement, and communal roosting on foraging success of North American vultures. Auk 113:473-488

Buckley NJ (1997) Spatial-concentration effects and the importance of local enhancement in the evolution of colonial breeding in seabirds. Am Nat 149:1091-1112

Camphuysen CJ, Webb A (1999) Multi-species feeding asso- 
ciations in North Sea seabirds: jointly exploiting a patchy environment. Ardea 87:177-198

Cherel Y, Bocher P, Broyer CD, Hobson KA (2002) Food and feeding ecology of the sympatric thin-billed Pachyptila belcheri and Antarctic P. desolata prions at Iles Kerguelen, Southern Indian Ocean. Mar Ecol Prog Ser 228:263-281

Chilton G, Sealy SG (1987) Species roles in mixed-species feeding flocks of seabirds. J Field Ornithol 58:456-463

Croxall JP, Prince PA (1980) Food, feeding ecology and ecological segregation of seabirds at South Georgia. Biol J Linn Soc 14:103-131

Croxall JP, Prince PA, Reid K (1997a) Dietary segregation of krilleating South Georgia seabirds. J Zool Lond 242: 531-556

Croxall JP, Prince PA, Rothery P, Wood AG (1997b) Population changes in albatrosses at South Georgia. In: Robertson G, Gales R (eds) Albatross biology and conservation. Surrey Beatty \& Sons, Chipping Norton, p 69-83

Daly KL, Macaulay MC (1988) Abundance and distribution of krill in the ice edge zone of the Weddell Sea, austral spring 1983. Deep-Sea Res 35:21-41

del Hoyo J, Elliott A, Sargatal J (eds) (1992) Handbook of the birds of the world, Vol I. Lynx Edicions, Barcelona

del Hoyo J, Elliott A, Sargatal J (eds) (1995) Handbook of the birds of the world, Vol IV. Lynx Edicions, Barcelona

Diamond J (1981) Mixed-species foraging groups. Nature 292:408-409

Duffy DC (1989) Seabird foraging aggregations: a comparison of two southern upwellings. Colon Waterbirds 12:164-175

Evans PGH (1982) Associations between seabirds and cetaceans: a review. Mamm Rev 12:187-206

Fraser WR, Pitman RL, Ainley DG (1989) Seabird and fur seal responses to vertically migrating winter krill swarms in Antarctica. Polar Biol 10:37-41

Gerard JF, Bideau E, Maublanc ML, Loisel P, Marchal C (2002) Herd size in large herbivores: encoded in the individual or emergent? Biol Bull (Woods Hole) 202:275-282

Gotmark F, Winkler DW, Andersson M (1986) Flock-feeding on fish schools increases individual success in gulls. Nature 319:589-591

Grover JJ, Olla BL (1983) The role of rhinoceros auklets (Cerorhinca monocerata) in mixed-species feeding assemblages of seabirds in the Strait of Juan de Fuca, Washington. Auk 100:979-982

Grunbaum D, Veit RR (2003) Black-browed albatross foraging on Antarctic krill: density-dependence through local enhancement? Ecology 84:3265-3275

Haney JC, Fristrup KM, Lee DS (1992) Geometry of visual recruitment by seabirds to ephemeral foraging flocks. Ornis Scand 23:49-62

Harrison NM, Whitehouse MJ, Heinemann D, Prince PA, Hunt GL Jr, Veit RR (1991) Observations of multispecies seabird flocks around South Georgia. Auk 108:801-810

Hoffman W, Heinemann D, Wiens JA (1981) The ecology of seabird feeding flocks in Alaska. Auk 98:437-456

Jouventin P, Weimerskirsch H (1990) Satellite tracking of wandering albatrosses. Nature 343:746-748

Mahon TE, Kaiser GW, Burger AE (1992) The role of marbled murrelets in mixed-species feeding flocks in British Columbia. Wilson Bull 104:738-743

Manly BJ (1997) Randomization, bootstrap, and Monte Carlo methods in biology, 2nd edn. Chapman \& Hall, London

Mitani JC, Grether GF, Rodman PS, Priantha D (1991) Associations among wild orang-utans: sociality, passive aggregations or chance? Anim Behav 42:33-46

Morse DH (1977) Feeding behavior and predator avoidance in heterospecific groups. Bioscience 27:332-339

Murphy RC (1936) Oceanic birds of South America. American
Museum of Natural History, New York

Nevitt GA, Veit RR, Kareiva P (1995) Dimethyl sulfide as a foraging cue for Antarctic procellariiform seabirds. Nature 376:680-682

Payne MR, Prince PA (1979) Identification and breeding biology of the diving petrels Pelecanoides georgicus and P. urinatrix exsul at South Georgia. NZ J Zool 6:299-318

Pielou EC (1977) Mathematical ecology. John Wiley, New York Porter JM, Sealy SG (1982) Dynamics of seabird multispecies feeding flocks: age-related feeding behavior. Behaviour 81:91-109

Powell GVN (1985) Sociobiology and adaptive significance of interspecific foraging flocks in the neotropics. In: Buckley PA, Foster MS, Morton ES, Ridgley RS, Buckley FG (eds) Neotropical ornithology, Ornithological Monographs No. 36. American Ornithologists Union, Washington, DC, p $713-732$

Pöysä H (1992) Group foraging in patchy environments the importance of coarse-level local enhancement. Ornis Scand 23:159-166

Prince PA (1980) The food and feeding ecology of blue petrel (Halobaena caerulea) and dove prion (Pachyptila desolata). J Zool Lond 190:59-76

Prince PA, Croxall JP, Trathan PN, Wood AG (1997) The pelagic distribution of South Georgia albatrosses and their relationship with fisheries. In: Robertson G, Gales R (eds) Albatross biology and conservation. Surrey Beatty \& Sons, Chipping Norton, p 137-167

Rau GH, Ainley DG, Bengtson JL, Torres JJ, Hopkins TL (1992) ${ }^{15} \mathrm{~N} /{ }^{14} \mathrm{~N}$ and ${ }^{13} \mathrm{C} /{ }^{12} \mathrm{C}$ in Weddell Sea birds, seals and fish: implications for diet and trophic structure. Mar Ecol Prog Ser 84:1-8

Reid, K, Croxall, JP, Edwards RM, Hill HJ, Prince, PA (1997) Diet and feeding ecology of the diving petrels Pelecanoides georgicus and $P$. urinatrix at South Georgia. Polar Biol 17:17-24

Rencher AC (1995) Methods of multivariate analysis. John Wiley, New York

Shealer DA (2002) Foraging behavior and food of seabirds. In: Schreiber EA, Burger J (eds) Biology of marine birds. CRC Press, Boca Raton, FL, p 137-177

Silverman ED, Veit RR (2001) Associations among Antarctic seabirds in mixed-species feeding flocks. Ibis 143:51-62

Simmons KEL (1972) Some adaptive features of seabird plumage types. Br Birds 65:465-479

Tasker ML, Jones PH, Dixon T, Blake BF (1984) Counting seabirds at sea from ships: a review of the methods employed and a suggestion for a standardized approach. Auk 101:567-577

Tremblay Y, Cherel Y (1999) Synchronous underwater foraging behavior in penguins. Condor 101:179-185

Veit RR (1988) Spatial dispersion patterns of Antarctic seabirds. PhD thesis, University of California, Irvine

Veit RR (1999) Behavioural responses by foraging petrels to swarms of Antarctic krill Euphausia superba. Ardea 87:41-50

Warham J (1990) The petrels: their ecology and breeding systems. Academic Press, London

Warham J (1996) The behaviour, population biology and physiology of the petrels. Academic Press, London

Weimerskirch $\mathrm{H}$, Salamolard $\mathrm{M}$, Sarrazin $\mathrm{F}$, Jouventin $\mathrm{P}$ (1993) Foraging strategies of wandering albatrosses through the breeding season: a study using satellite telemetry. Auk 110:325-342

Wittenberger JF, Hunt GL (1985) The adaptive significance of coloniality in birds. Avian Biol 8:1-78

Zar JH (1999) Biostatistical analysis, 4th edn. Prentice Hall, New York 